Pawel FUC

Andrzej ZIOLKOWSKI

Lech SWIATEK

Pawel MELWINSKI

\title{
Tests of a prototype spark-ignited, direct-injection engine powered by JET-A1 fuel
}

The article presents a part of the work done in a research and development project being made by SWIATEK Lech Swiatek company. It describes the comparison of different fuels used in piston engines with JET-Al turbine engine fuel. Next, the proposed combustion process of JET-A1 fuel and a prototype one-cylinder engine are described. In details, a special cylinder head and direct injection programmable computer are presented. In the next part, a designed and built test stand is described. Finally, the results and conclusions are presented. The designed test stand enabled to perform assumed tests. The innovative JET-Al combustion process was possible to perform and the power and torque were higher in 1900-3000 rpm range than with the gasoline fuel. The designed GDI programmable injection computer enabled to fully control the injection and ignition parameters.

Key words: alternative fuel, test engine, piston aircraft engines, jet-al

\section{Introduction}

The work was carried out as part of a research and development project in the National Centre for Research and Development "INNOLOT" program titled "Development of an innovative aviation engine fueled with JET-A1 fuel". The project fits into environmentally friendly transport solutions.

The aim of the project is to develop the conditions of the combustion process in a JET-A1 fueled piston engine, used for aviation turbine engines. As part of the project, two prototypes of piston engines with different parameters will be developed, intended for use in ultralight and light aircraft. These engines will have a reduced emissivity compared to currently used aircraft piston engines.

One of the stages of the project are tests made on engine models. As part of this stage, a prototype 1-cylinder research engine was developed and made together with a water-brake station and the possibility of feeding two types of fuels. The research was carried out on the test stand, and the results are presented in this article.

\section{JET-A1 Fuel characteristics}

Table 1 shows the comparison of properties of different liquid fuels. The JET A-1 fuel is intended for the propulsion of turbine aircraft engines. Diesel and gasoline are used in combustion engines of various motor vehicles. AVGAS $100 \mathrm{~L}$ is a gasoline designed for spark-ignition reciprocating piston engines. Each of these fuels must comply with separate normative requirements, therefore it is impossible to accurately compare them taking into account the standards. For this reason, on the basis of literature, some values have been averaged and rounded to the extent enabling the comparison of selected fuels and are presented in Table 1. Additionally, the results of laboratory tests of JET-A1 fuels from 3 producers are presented.

The JET A-1 fuel is a kerosene fraction in which there are lighter hydrocarbons than in diesel. The ASTM standard does not specify the cetane number of this fuel because it is not an important parameter for turbine engines. According to the available data, it has an octane number 8 and a cetane number of 50 . It can be used for spark ignition engines with a low compression ratio or for compressionignition engines with low ignition delay and extended combustion time compared to diesel [2]. When using fuel for reciprocating engines, it may be necessary to use additives that increase the cetane number. In addition, JET-A1 has a lower viscosity and significantly lower lubricity. For this

Table 1. Comparison of properties of selected liquid fuels (* - results of tests of JET-A1 fuels from 3 manufacturers) [3,6]

\begin{tabular}{|c|c|c|c|c|c|}
\hline \multirow[b]{2}{*}{ Parameter } & \multirow[b]{2}{*}{ Unit } & \multicolumn{4}{|c|}{ Fuel } \\
\hline & & JET-A1 & $\begin{array}{c}\text { Diesel oil Ekodiesel } \\
\text { ULTRA }\end{array}$ & Gasoline & AVGAS 100LL \\
\hline Density in temp. $15^{\circ} \mathrm{C}$ & $\mathrm{kg} / \mathrm{m}^{3}$ & $\begin{array}{c}795-808 * \\
775-840\end{array}$ & $820-845$ & $720-755$ & $690-790$ \\
\hline Calorific value & $\mathrm{MJ} / \mathrm{kg}$ & $\begin{array}{c}43.1-43.3^{*} \\
42.8\end{array}$ & $42.0-44.0$ & 44.0 & $\min .43 .5$ \\
\hline Octane number & MON & 8.0 & & $95.0-98.0$ & $\min .99 .6$ \\
\hline Cetane number & - & 50.0 & $\min .51 .0$ & - & 5.0 \\
\hline $\begin{array}{l}\text { Crystallization temperature, } \\
\text { max. }\end{array}$ & ${ }^{\circ} \mathrm{C}$ & $\begin{array}{c}\text { from }-65.0 \text { to }-50.5^{*} \\
-47.0\end{array}$ & - & approx. -40.0 & -58.0 \\
\hline Ignition temperature & ${ }^{\circ} \mathrm{C}$ & $\begin{array}{c}41.5-44.5^{*} \\
38 \\
\end{array}$ & 56 & -40 & $<0$ \\
\hline $\mathrm{CO}_{2}$ emission & $\begin{array}{l}\mathrm{kg} \mathrm{CO}_{2} / \\
\mathrm{kg} \text { fuel }\end{array}$ & 3.4 & - & 3.3 & 3.3 \\
\hline Sulfur content & $\mathrm{mg} / \mathrm{kg}$ & $\begin{array}{c}50-1780^{*} \\
\max .3000 .0\end{array}$ & $\max .10 .0$ & $\max .10 .0$ & Max. 500.0 \\
\hline
\end{tabular}


reason, it was decided to use subassemblies of the direct gasoline injection system and thus the fuel without lubricating properties. In relation to diesel fuel, the advantage of JET-A1 fuel is the low temperature of crystallization, reaching a maximum of $-47^{\circ} \mathrm{C}$. The sulfur content can be over 300 times higher than in the case of diesel or motor gasoline. The ignition temperature is about 20 degrees lower than diesel.

The emission of carbon dioxide during the combustion process is similar for all fuels. Current research shows that the use of JET-A1 fuel in a compression-ignition engine produces higher emissions of carbon monoxide (CO), smoke and a decrease in $\mathrm{NO}_{\mathrm{x}}$ emissions [5].

\section{JET-A1 combustion process concept}

Currently, aviation Diesel engines with a high compression ratio are also manufactured in the world [4]. They can be also powered by JET-A1 fuel and find application in light aircraft with MTOW between 450 and $5670 \mathrm{~kg}$. In addition, several small engine designs for drone propulsion are being developed. They are characterized by different solutions of the combustion process: these are engines operating in a two- or four-stroke cycle, with spark or selfignition, with reciprocating or rotary pistons. Special processes for preparing the mixture are also implemented, for example with the use of compressed air for mixture preparation [1]. Because of their limited TBO time and low power, these engines can not be used for ultra-light and light planes propulsion.

In the research project, the process of JET-A1 fuel combustion in a spark-ignition engine with a low compression ratio was selected. This process results in lower loads of the components of the crankshaft system in relation to highpressure Diesel engines, which enables that the engine elements can be lighter. Due to differences in fuels, it was necessary to check the process on a model test engine.

Assumptions related to the combustion process:

1. The operating pressure of GDI gasoline injection systems is max. 150-200 bar, so it was assumed that considering the viscosity of the lower JET A-1 fuel than diesel fuel, the fuel atomization will be sufficient. In older generations of mechanical injection systems of diesel engines, installations were working properly on diesel fuel pressures not much higher than 100 bar.

2. Distributing the injection dose into two parts (Fig. 1): one during the inlet stroke the second in the area of the start of the working stroke will be able to burn the JET A-1 fuel with the danger of burning detonation. The designed controller enables the adjustment of both the size of both doses and their angular position.

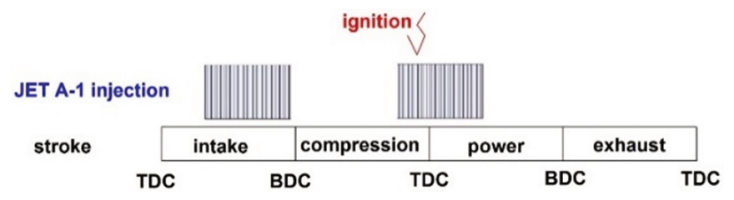

Fig. 1. Distribution of doses of JET A-1 fuel injection

\section{Description of the prototype research engine}

A prototype 1-cylinder test engine "SB-01" was built. The basic construction for the test engine was a four-stroke, overhead-valve engine with a boxer cylinder system -
VW 1600B. Its displacement was $1583 \mathrm{~cm}^{3}$ and the maximum power was $32 \mathrm{~kW}$. It uses a carbureted fuel supply system and air-cooling. Table 2 shows a comparison of the parameters of both basic and prototype engine.

As part of engine modification, three cylinders were dismantled and blinded. On the free rod-journals of the crankshaft, there were masses installed for balancing the engine. The working cylinder had a bigger bore and piston with $94 \mathrm{~mm}$ diameter. New flywheel with increased weight was made and mounted.

Table 2. Technical data of the basic and prototype engine

\begin{tabular}{|c|c|c|}
\hline Parameter & \multicolumn{2}{|c|}{ Value } \\
\hline Engine type & VW 1600 B & SB-01 \\
\hline Displacement $\left[\mathrm{cm}^{3}\right]$ & 1584 & 478 \\
\hline Cylinder layout & boxer & - \\
\hline Cylinder numer & 4 & 1 \\
\hline Bore $[\mathrm{mm}]$ & 85.5 & 94 \\
\hline Stroke [mm] & \multicolumn{2}{|c|}{69} \\
\hline Compression ratio & 7.5 & 9.5 \\
\hline Maximum power $[\mathrm{kW}]$ & 32 at $4000 \mathrm{rpm}$ & - \\
\hline $\begin{array}{l}\text { Maximum torque } \\
{[\mathrm{N} \cdot \mathrm{m}]}\end{array}$ & 106 at $2200 \mathrm{rpm}$ & - \\
\hline Cooling system & Air-cooled & $\begin{array}{l}\text { Crankcase and cylin- } \\
\text { der air-cooled, } \\
\text { cylinder head liquid- } \\
\text { cooled }\end{array}$ \\
\hline Injection system & Carbourated & Direct injection \\
\hline Ignition & $\begin{array}{l}\text { Single, mechanical- } \\
\text { ly controlled }\end{array}$ & $\begin{array}{l}\text { Single, electronically } \\
\text { controled }\end{array}$ \\
\hline
\end{tabular}

A cylinder head consisting of three parts was made for the engine, which enables easy change of the shape of the combustion chamber and the position of injectors and sparkplugs (Fig. 2). Due to the need for long-term tests, liquid cooling was used in the head. In the lower part (1) there are side walls of the combustion chamber, part of the water jacket and the injector seat (2). The middle part (3) contains the chamber roof, intake (5) and exhaust (6) channels, valve system, the second part of the water jacket with the inlet (7) and the spark plug socket (8). In the upper part (9) the valve rocker system is situated.

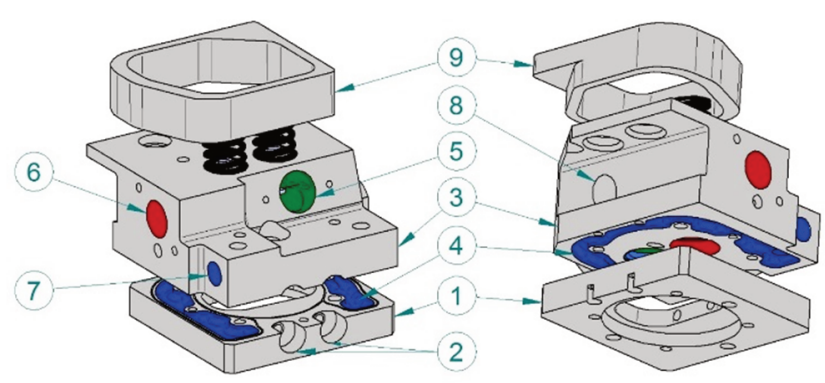

Fig. 2. Prototype cylinder head: 1 - lower part with combustion chamber and water jacket, 2 - injector seats, 3 - middle part, 4 - water jacket, 5 - intake channel, 6 - exhaust channel, 7 - cooling system inlet, 8 - spark plug socket, 9 - upper part

The JET-A1 fuel system used in the SB-01 engine uses elements of the direct gas injection system GDI: the Bosch high-pressure pump 04E127026E and the single Bosch injector 04E133036A. A programmable computer devel- 
oped for the needs of the project was used to control the injection and ignition process (Fig. 3). During engine operation, the following input data were collected: crankshaft and camshaft positions, intake air temperature, throttle position, oxygen content in the exhaust gasses and pressure in the fuel system. Based on these parameters, the computer controlled the opening time and the injector opening point according to the programmed injection maps. In addition, it was possible to divide the injection dose into two phases. The ignition point was also controlled using separate maps.
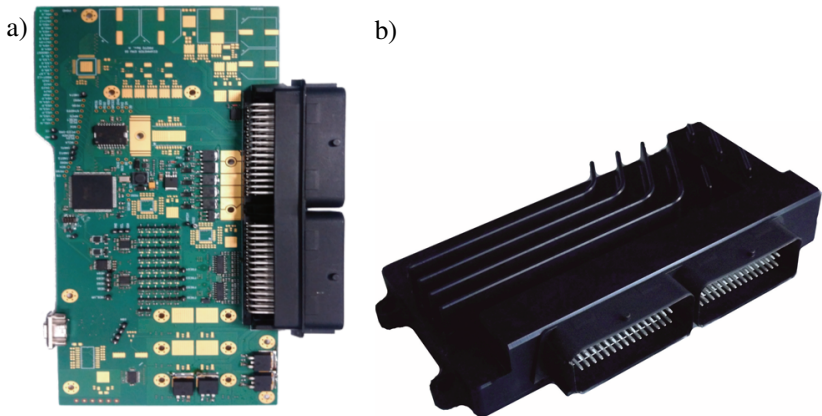

Fig. 3. Programmable computer of the direct injection system GDI a) view of the upper layer of the computer board, b) computer casing

\section{Description of the test stand}

To carry out comparative tests on the combustion of gasoline and JET-A1 fuel in the assumed process, the test stand marked SBB was designed and constructed (Figs 4 and 5). The tested motor (1) was connected by a clutch to the water brake HW200 (4). The engine speed was read using the encoder (4). The torque was measured on the brake by means of a strain gauge (6). The stand was equipped with two fuel tanks (7) with the possibility of changing the power source for the engine fuel system. The stand enables the measurement of the motor characteristics (power and torque in relation to revolutions) and work under load.

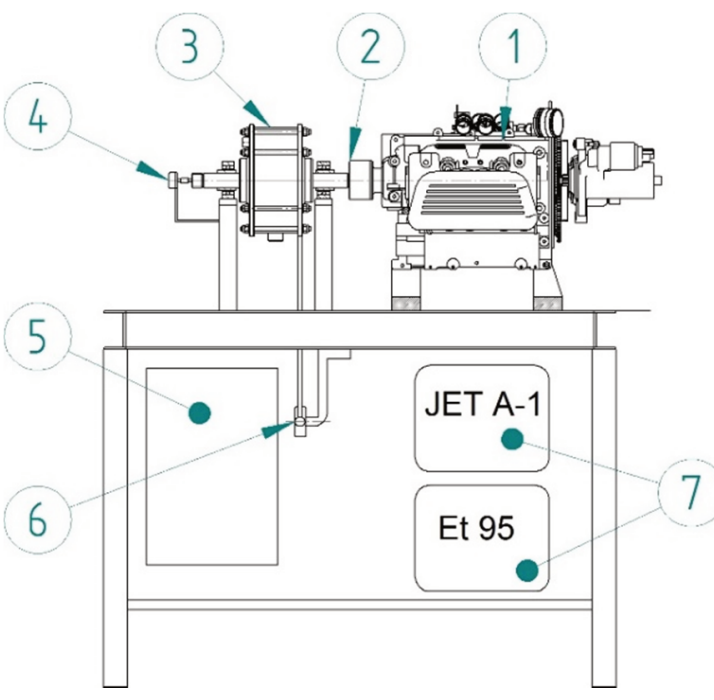

Fig. 4. SBB test stand scheme: 1 - prototype 1-cylinder engine, 2 - clutch, 3 - water brake HW 200, 4 - encoder, 5 - measuring box, 6 - strain gauge, 7 - fuel tanks

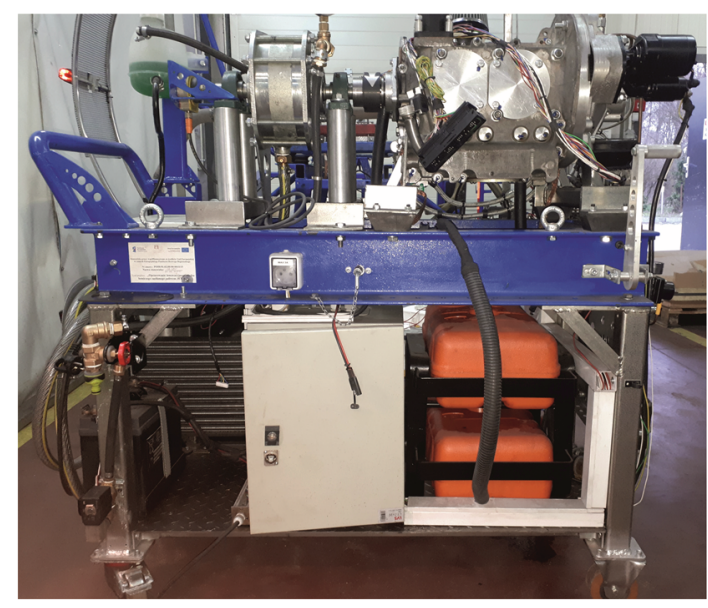

Fig. 5. SBB test stand

\section{Results}

The tests were carried out in two stages. In the first stage, the engine was powered with EuroSuper 98 gasoline. Engine startup tests and work tests were carried out in the range from 1000 to $3600 \mathrm{rpm}$. The engine characteristics were obtained with gasoline.

In the second stage, the engine was powered by JET-A1 fuel. Initially, during the increase of the load, there was knocking combustion. In order to eliminate it, the fuel dose was divided into two phases, injected in the intake and compression cycle. Thanks to these changes, the maximum power and engine load were achieved. As a result of the tests, the engine characteristics were obtained (Fig. 6).

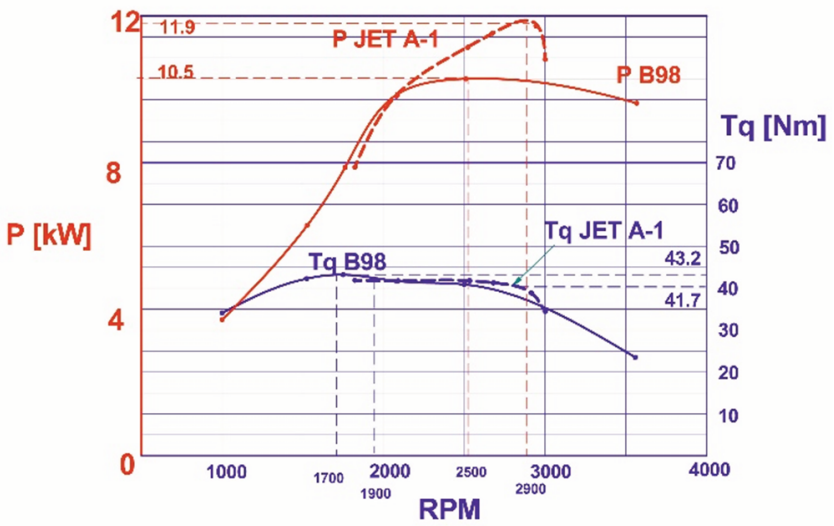

Fig. 6. Comparison of characteristics of a prototype engine powered by JET-A1 fuel and EuroSuper 98 petrol

The engine powered with gasoline obtained a low-speed characteristic with a $10.5 \mathrm{~kW}$ maximum power at $2500 \mathrm{rpm}$ and a $43.2 \mathrm{Nm}$ maximum torque at $1700 \mathrm{rpm}$.

The engine running on JET A-1 fuel obtained a very flat torque curve with a $41.7 \mathrm{Nm}$ maximum at $1900 \mathrm{rpm}$ and falling down above $3000 \mathrm{rpm}$. In the range 1900-3000 rpm, the torque developed by the engine working on the JET A-1 is higher than when working on gasoline. The engine worked evenly under full load one hour and there was no knocking phenomenon. Combustion was softer and quieter than on gasoline. 


\section{Conclusions}

As part of the research, the following conclusions were formulated:

- The designed and constructed test stand made it possible to carry out the assumed tests and verify the combustion process assumptions.

- The assumed innovative process of JET-A1 fuel combustion in the engine with low compression ratio and spark ignition is possible and is very efficient - in the range $1900-3000 \mathrm{rpm}$ the torque and power are higher than on gasoline.

- Designed direct injection computer enables full control of the combustion process in the test engine and the ob- tained results prove the assumptions related to the JET

A-1 fuel injection and ignition system.

The direction of further work should include examination of other injector settings and optimization of injection parameters in order to increase the obtained power. It will also be necessary to carry out tests on a 4-cylinder engine equipped with a different intake system.

\section{Acknowledgements}

The authors are pleased to acknowledge the financial support from the National Centre of Research and Development in the framework of Innolot contract POIR/01.02.00-00-0015/1510 for the work presented in this paper.

\section{Nomenclature}

ASTM American Society of Testing and Materials

BDC bottom dead center

GDI gasoline direct ignition

MTOW maximum takeoff weight

MON motor octane number

TBO time between overhaul

TDC top dead center

\section{Bibliography}

[1] DUTCZAK, J. Heavy fuel engines. Combustion Engines. 2015, 154(4), 34-46.

[2] LUFT, S. Podstawy budowy silników. Wyd. 2, WKiŁ, Warszawa 2006.

[3] PAGOWSKI, Z. Lotnicze paliwa i oleje. Prace Instytutu Lotnictwa. 2009, 4(199), 117-127.
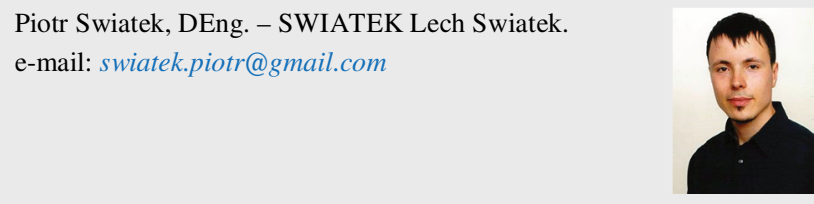

Pawel Fuc, DSc., DEng. - Faculty of Transport Engineering, Poznan University of Technology. e-mail: pawel.fuc@put.poznan.pl Engineering, Poznan University of Technology. e-mail: andrzej.j.ziolkowski@put.poznan.pl
[4] PAGOWSKI, Z. Pozytywne skutki zastosowania silników Diesla w lotnictwie. Prace Instytutu Lotnictwa. 2016.

[5] SOLMAZA, HAMIT, et al. Investigation of the effects of civil aviation fuel Jet A1 blends on diesel engine performance and emission characteristics. Indian Journal of Engineering and Materials Sciences. 2014, 21(2), 200-206.

[6] Fuel producers data.
Lech Swiatek, MSc. - SWIATEK Lech Swiatek. e-mail: lech@swiatek.com.pl

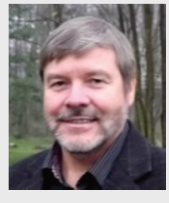

Pawel Melwinski, Eng. - SWIATEK Lech Swiatek. e-mail:pmelwinski@gmail.com

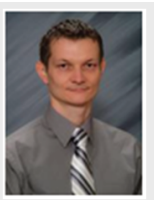

